\title{
Sobre "Sandino. Una biografía política" de Volker Wünderich
}

Por José Luis Rocha

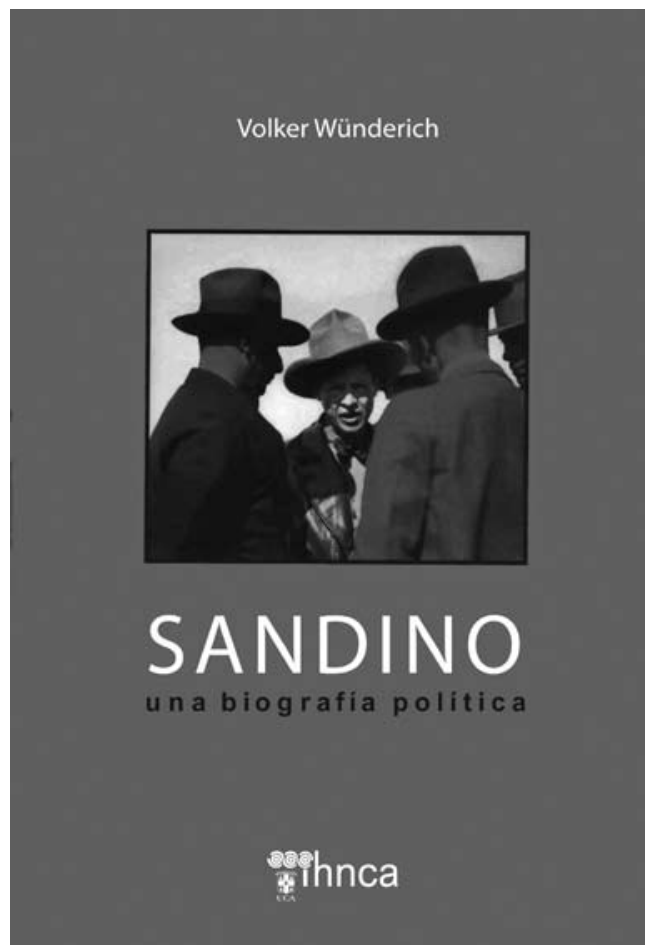

Imagino a Volker en la Nicaragua de los 80, una Nicaragua por la que las dos Alemanias -Federal y Democrática- estaban apostando tanto. Lo imagino recorriendo las candentes calles de Managua, holgadas para el parque vehicular de aquellos días, aunque no tanto para algunas pintorescas donaciones alemanas: los temibles IFAs ${ }^{1}$-a cuyas siglas fue jocosamente reasignado el significado "Imposible Frenar A tiempo"- y aquella gigantesca cocina mecánica -quizás Volker se topó con ese armatoste verde olivo sin saberque en cuestión de minutos podía preparar 500 huevos revueltos, arroz para dos batallones y, si la operaba el ingenio de la mano de la temeridad, un gallo pinto en tiempo y forma para halagar el paladar vernáculo.

Imagino a Volker comedido en sus conjeturas, riguroso en la comprobación de hipótesis, afanoso en el acopio de documentos, una ardua tarea que tropezaba con el vacío que hereda la mucha oralidad y poca escritura de nuestra historiografía. Luego tuvo que volcarse sobre la inmensa masa de papeles: informes de sucesivos diplomáticos alemanes ante su gobierno, reportes del departamento naval y el cuerpo de marines de los Estados Unidos, archivos de la iglesia morava, correspondencia de la oficina de asuntos exteriores del gobierno británico, periódicos y revistas de la época -no sólo de Nicaragua, sino también de México, Perú, Costa Rica, Argentina, Alemania, Estados Unidos-, memorias de personajes y personajillos, tomacos sobre movimientos obreros y mesiánicos, mamotretos sobre la política estadounidense hacia Nicaragua y sobre la política e historia mexicana, libros inolvidables como el reportaje "Maldito país" que el periodista nicaragüense José Román realizó en 1933 y que sólo pudo publicar medio siglo después (Volker lo consiguió recién salido del horno editorial), y numerosas biografías de Sandino, desde la excesivamente glorificadora de Edelberto Torres Espinosa hasta la denigrante "El verdadero Sandino o el calvario de las Segovias" de Anastasio Somoza García, pasando por las de Gregorio Selser, quizás el más leído de los biógrafos sandinistas, y las de Sofonías Salvatierra y Neill Macaulay. La montaña no podía excluir, 
por supuesto, la compilación de cartas, pronunciamientos y otros textos realizada por Sergio Ramírez y publicada bajo el título "El pensamiento vivo de Sandino". Toda esta revisión, acopio, lectura, clasificación, análisis y muchos otros esfuerzos son parte insoslayable de una investigación rigurosa. El lector poco avisado los pasa por alto, el activista los desprecia y al político ávido de manipulación le suenan superfluos.

El contexto en que el libro fue concebido y escrito no era el más propicio. No para este libro. Soplaban vientos huracanados de loas, fanfarria y ditirambos al héroe. ¿A quién se le ocurre venir a buscar y contar la verdad -o cuando menos una parte y un aspecto de la misma- en una Nicaragua donde la inflación monetaria y mitológica iban de la mano y donde muchos estábamos bastante contentos con las mentiras piadosas, mentiras blancas, mentiras negras y rojinegras? A un historiador aguafiestas que aterrizó en una inmensa catedral de 130 mil kilómetros cuadrados dedicada a Sandino, con puertos, escuelas, fábricas, villas, calles, plazas, parques y barriadas bautizadas o rebautizadas en su nombre y adornadas con su busto, su retrato, su silueta o simplemente una elipse retorcida para insinuar el sombrero de ala ancha.

Eran los tiempos en que el FSLN trasladó a Abelardo Cuadra desde Venezuela para que identificara el sitio donde habían fusilado a Sandino, en cuyas inmediaciones aún se tenía la esperanza de encontrar sus restos. No faltarían hornacinas en que guardarlos y exponerlos a la veneración pública. No hubo restos y entonces cantamos "La tumba del guerrillero", composición de Carlos Mejía Godoy inspirada en un poema de Ernesto Cardenal: "Y por eso tu tumba es todito nuestro territorio. En cada palmo de mi Nicaragua ahí vos estás." Eran los tiempos de la "Ronda tribal para el nacimiento de Sandino" de Julio Valle-Castillo, un poema bellísimo donde el nacimiento de Sandino se aroma con incienso, se canta con coros griegos y se pinta con óleos de pesebre cristiano. Eran los tiempos en que se gritaba, sustituyendo el nombre de Cristo por el de Sandino en la conocida frase paulina: "Sandino ayer, Sandino hoy, Sandino siempre."

A ese nicho ecológico vino Volker con aviesas intenciones: manosear el santo con las manos sucias. Sucias de ciencia y categorías de historiador. Volker tuvo que ponderar hasta qué punto se sostenían la leyenda, las etiquetas, las tesis de un Sandino siempre lúcido y dueño de la situación. Un Sandino hecho a base de consignas y laminado en oro. Tuvo que desbrozar oropeles y guirnaldas para llegar al Sandino humano, falible, dubitativo, con olfato político a veces muy averiado, tomador de buenas, regulares y también pésimas decisiones. Tomó su material y lo dotó de un sentido. Quiero mencionar aquí, de forma muy puntualizada, tres de los aspectos que más me impresionan en este Sandino fruto de un trabajo científico:

1. El papel de la religiosidad en el ideario de Sandino. Sus contactos, iniciaciones y avances en diversos movimientos espiritistas y muy especialmente en la "Escuela Magnético Espiritual de la Comuna Universal" y la logia masónica, donde alcanzó el nivel de maestro en tercer grado. No estuvo en esto alejado de muchos notorios personajes de su época. El presidente mexicano asesinado Francisco Madero, el caudillo más querido en los inicios de la revolución mexicana -que alzó la bandera contra la reelección en general y muy en particular contra la de Porfirio Díaz-, fue declarado por más de un historiador una especie de místico de la política debido a sus motivaciones netamente espirituales. Si 
Madero platicaba y pedía consejos a los muertos -sobre todo a Benito Juárez-, Sandino sostenía que Pedrón y otros de sus compañeros ya habían combatido junto a él en vidas anteriores. La vena espiritista sin duda fue una argamasa imprescindible para mantener la cohesión de su tropa, soportar la montaña y sus asperezas y resistir a los halagos de aduladores idealistas o interesados. Posiblemente también operó como un filtro que sesgó la visión política. Pero lo importante aquí, al margen de las fobias o filias que suscite este rasgo de Sandino, es el desafío que su exploración lanza a la historiografía. Hay que aplicar una hermenéutica más exigente a los textos. Volker empezó esta línea de forma muy rica, indagando, por ejemplo, los vínculos de ese espiritismo con la modernización de una sociedad que aún vivía los resabios de la anarquía poscolonial.

2. El Sandino prisionero de sus orígenes políticos: "Durante todo el transcurso de la guerra -explica Volker-, Sandino no pudo separarse del Partido Liberal para fundar una fuerza política propia. Hasta 1932 sostuvo la ficción de estar luchando en nombre del Partido Liberal 'traicionado'." Pero, por otro lado, también reconoce que Sandino convoca a una guerra contra la voluntad de ambas facciones de la oligarquía y se convierte en jefe de bandidos y por eso es acusado de abrir las puertas de la anarquía social. Las raíces liberales de Sandino aparecen en otros textos, pero este Sandino que vive la tensión entre su apertura a otras corrientes ideológicas y el liberalismo en el que está atrapado me resulta más consistente con sus decisiones y pronunciamientos.

3. Finalmente, el Sandino que realmente no fue político. No, al menos, un político de colmillo retorcido. Ahí están para demostrarlo su incapacidad para entender a los políticos mexicanos en quienes quiso ver, contra todos los signos de los tiempos, unos potenciales aliados en nombre de una solidaridad revolucionaria y panlatinoamericanista. El Sandino de Volker naufragó en el monitoreo y en el marketing político. ¿Para bien o para mal? No sabemos. Pero lo cierto es que de la mano de su miopía política caminaba su entereza moral y su renuencia a venderse o rendirse, esas que, nos señala Volker, incomodaban a tantos que posiblemente respiraron aliviados con la desaparición de Sandino.

¿Por qué reeditar, releer y leer desde el hoy y el aquí esta biografía sin concesiones a la mitomanía ni al deleite iconoclasta? No por ser Sandino un mito al borde del barranco al que la posmodernidad arrastra sin remisión a la huesera de veneraciones modernas, atiborrada del romanticismo de la gloria, la solidaridad que ya parece no enternecer a los pueblos, la autodeterminación, entre otros artefactos de la cultura política casi en desuso. No por eso, sino porque Sandino vive y crece en el debate nacional, donde se apela a su santo y seña para legitimar posiciones encontradas e incluso para legitimar opciones mágico-religiosas. Como el San Pedro del poema de Alberti, hoy Sandino corre el riesgo de quedarse "sentado, en bronce inmovilizado". Y también arrancado del contexto y manipulado. Por eso importa reeditar, releer y leer desde el hoy y el aquí esta biografía sin concesiones a la mitomanía, una biografía - no hagiografía- que presenta un Sandino rigurosamente apegado a sus hechos y estrategia política.

Este libro quizás se ubica al otro lado de un quiebre cultural. Las nuevas generaciones de lectores lo dirán. De este lado acechan el pragmatismo, el relativismo y la fragmentación 
posmodernos. Desde el Sandino como calvario de las segovias de su verdugo Somoza hasta el General de hombres libres de Gregorio Selser, pasando por los de Román, TorresEspinosa, Belastingüingoitia, Beals y Ramírez, hay Sandinos para todos los paladares, podría reclamar el cinismo relativista. Sin embargo, el Sandino de esta biografía política satisface un hambre y responde a una pregunta crucial. Satisface un hambre de horizonte político porque muestra cómo arar nuevos surcos con los bueyes y restricciones que las circunstancias dan. Y responde a una pregunta eterna tan antigua y acuciante como la historia: ¿Qué lugar tiene la ética en la política? Veamos, leamos cómo la contesta este Sandino de carne y savia que Volver Wünderich ha delineado con arte y ciencia.

\section{Notas}

1 Industrieverband Fahrzeugbau der DDR (German state-controlled vehicle manufacturing company). 